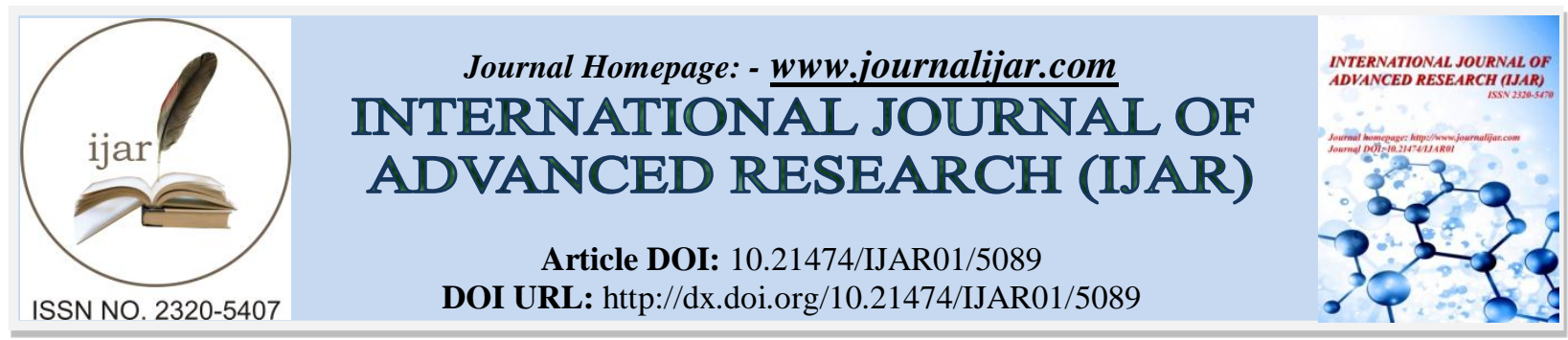

RESEARCH ARTICLE

\title{
COST ANALYSIS OF AFGHANISTAN BASIC PACKAGE OF HEALTH SERVICE: COST DRIVERS OF BPHS IN BAMYAN PROVINCE.
}

Dr. Abdullah Qarizada.

JSPH (Jodhpur School of Public Health), Department of Public Health, Maulana Azad University.

\section{Manuscript Info}

Manuscript History

Received: 06 June 2017

Final Accepted: 08 July 2017

Published: August 2017

Key words:-

Ridge splitting, Expansion, Guided bone regeneration.

\begin{abstract}
Background: Several modifications have been applied to the ridge splitting with or without expansion technique to allow for implant placement in the atrophic ridges. Some studies utilized guided bone regeneration and others not. Aim: This systematic review will try to present the different studies discussing the effects of conjunction of bone grafting materials and/or membranes or not with the ridge splitting with or without expansion for patients having insufficient bucco-palatal ridge width. Methods: A thorough PUBMED (Medline) and COCHRANE databases search in addition to hand-search of journals of relevance was performed on related terms in the period from 1992 to 2016 and resulted in 3247 titles of which 21 abstracts were selected and collected as full articles for further evaluation while the rest were excluded by title or abstract. According to the inclusion criteria 14 studies were included and discussed in this article. Results: Of the 14 studies included in the present study only one study (cohortretrospective) compared ridge splitting with/without expansion technique alone and with guided bone regeneration. Twelve studies applied guided bone regeneration while three studies did not.
\end{abstract}

Copy Right, IJAR, 2017,. All rights reserved.

\section{Acknowledgement:-}

First of all, I would like to express my deepest gratitude to the Jodhpur School of Public Health Maulana Azad University for great opportunity and productive initiative as well as MPH program.

I owe my sincere thanks and deepest gratitude to Dr. Latika Nath Sinha for her intensive support, invaluable feedbacks and great guidance, and also Dr. Sayed Khalil Ahmad (Co- Guide) and Dr. Mohammad Hamid Sina they have strongly supported me to go through all the steps in this study with their kind understanding, and remarkable patience.

My special thanks go to Dr. Pramila Vivak, Dr.Nitin Joshi, Dr. Gita Sinha, Mr. Harish, Mrs. Trupti Desie and other respectable JSPH \& MAU members for their kind patience, support and facilitation.

Corresponding Author:- Abdullah Qarizada.

Address:- JSPH (Jodhpur School of Public Health), Department of Public Health, Maulana Azad 
Dedication:- To the People of my Lovely country Afghanistan and my noble family
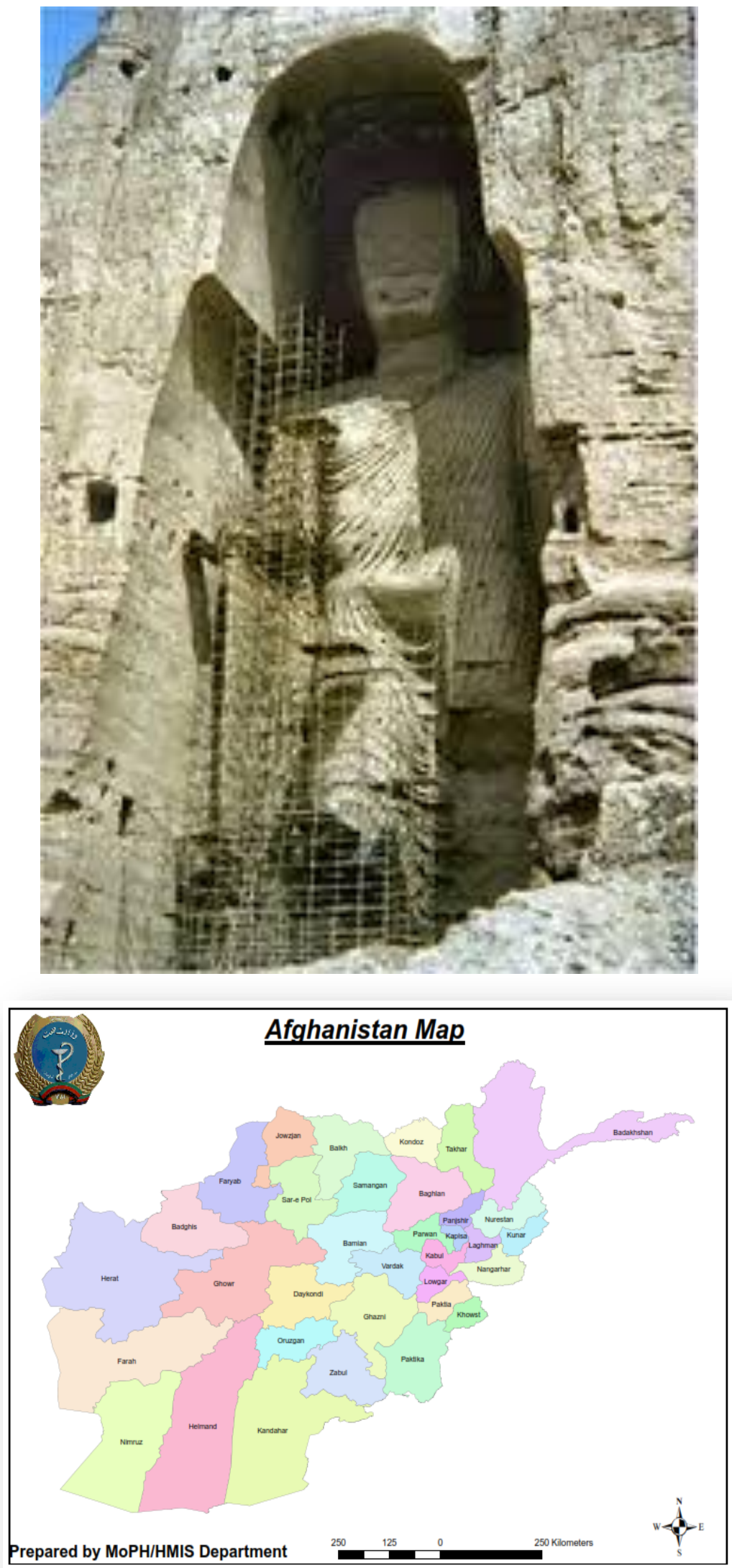


\section{Acronyms:}

$\begin{array}{ll}\text { BARAN } & \text { Bu Ali Rehabilitation \& Aid Network } \\ \text { BHC } & \text { Basic Health Center } \\ \text { BPHS } & \text { Basic Package of Health Services } \\ \text { CHC } & \text { Comprehensive Health Center } \\ \text { CHC+ } & \text { Comprehensive Health Center Plus } \\ \text { DH } & \text { District Hospital } \\ \text { EPHS } & \text { Essential Package of Hospital Services } \\ \text { EU } & \text { European Union } \\ \text { GIRoA } & \text { Government of the Islamic Republic of Afghanistan } \\ \text { HEFD } & \text { Health Economics and Financing Directorate } \\ \text { HP } & \text { Health Post } \\ \text { HSC } & \text { Health Sub-Center } \\ \text { MHT } & \text { Mobile Health Team } \\ \text { MoPH } & \text { Ministry of Public Health } \\ \text { MoPH-SM } & \text { Ministry of Public-Strengthening Mechanism } \\ \text { NGO } & \text { Nongovernmental Organization } \\ \text { PPR } & \text { Priority Reform and Reconstruction } \\ \text { USD } & \text { US Dollar } \\ \text { USAID } & \text { United States Agency for International Development }\end{array}$

\section{Executive Summary:-}

BPHS services were first rolled out in 2003 under the stewardship of the MoPH, and are financed largely by donors. This study aims to explore the costs of the BPHS and is intended to guide planning and coverage of the package in the coming years.

Table 1:- Summary of Per capita cost by facility

\begin{tabular}{|l|l|}
\hline Facility Type & USD \\
\hline Health Sub Center & 4 \\
\hline Basic Health Center & 3 \\
\hline Comprehensive Health Center & 6 \\
\hline District Hospital & 19.7 \\
\hline
\end{tabular}

This study samples one province (Bamyan) and costs service provision in 55 health facilities, using data compiled from June 1, 2015 - May 31, 2016. Bothe descriptive and inferential analyses of the cost data have been carried out on both the individual sample districts as well as provincial wide. Table 1 present a summary of the findings.

Consider the health facilities, the per capital expenditure for BPHS is on average, USD 8 And ranges from USD 19.7 (District Hospital) to USD 3 (Basic Health Center) aver when the expected number of patients treated in those centers and denominator (table 3 catchment population). For the districts, the average per capita expenditure for BPHSs is USD 8.

The difference in the per capita expenditures between the health facilities could be due to the differences in population characteristics defenses in care provision or case-mix. Hence, these figures should be interpreted with caution as I was unable to capture the number of patients treated across facilities or by case mix. Despite these limitation, these figures and the results point to the importance of capturing major cost-drivers within BPHS facilities across Bamyan Province This information is needed to help decision makers understand how much is being spent on BPHS and how much more will be required in the future as health priorities change. In addition, this information may be used to estimate how efficiently or cost-effectively resources are being used and where resource adjustments can be made to reduce cost and optimize outcomes. 
Table 2:- Summary of Per capita by District

\begin{tabular}{|l|l|l|l|l|l|l|}
\hline & \multicolumn{3}{|l|}{ Number and Types of HFs } & & \multirow{2}{*}{ Cost Per Capita/USD } \\
\hline Districts & SHC & BHC & CHC & DH & & \\
\hline Bamyan & 3 & 1 & 3 & 0 & & 5 \\
\hline Kahmard & 0 & 3 & 1 & 0 & 4 \\
\hline Panjab & 4 & 4 & 1 & 1 & & 8 \\
\hline Saighan & 0 & 2 & 1 & 0 & 5 \\
\hline Waras & 7 & 5 & 1 & 1 & 5 \\
\hline Yakawalang & 4 & 3 & 3 & 1 & 8 \\
\hline
\end{tabular}

\section{Introduction \& Background:-}

\section{The Basic Package Of Health Services:-}

Overcoming the fragility of health systems in post-conflict countries such as Afghanistan requires that governments, donors, and non-governmental organizations (NGOs) sit on a common platform to support critical health priorities and allocation of resources in a coordinated fashion. In March 2002, a forum similar to this informed the thinking behind the Basic Package of Health Services (BPHS). The BPHS, which was rolled out the following year, has two purposes: to provide a standardized package of basic services which forms the core of service delivery in all primary health care facilities; and to promote a redistribution of health services by providing equitable access, especially in underserved areas. The BPHS provides a comprehensive list of services; maternal and newborn health; child health and immunization; public nutrition; communicable disease control; mental health care; and disability referrals. It also includes a supply of essential drugs offered at all BPHS health facilities.

Building on the experiences of Cambodia and recognizing its limitations in health care provision, Afghanistan's Ministry of Public Health (MoPH) has contracted out health services to a network of local and international NGOs in 31 provinces. Ninety-five percent of the country's population resides in these province with the major funding agencies-European Union, the United States Agency for International Development (USAID) and the World Bank - funding the provision of BPHS. In the province of Kapisa, Panjshir and Parwan, the BPHS is being delivered through the Ministry of Public Health Strengthening Mechanism (MoPH-SM), a pilot program supported financially by the World Bank, where management is contracted under the same conditions and targets set for NGOs.

\section{Progress And Challenges Since 2003:-}

BPHS is currently being offered nationwide through 67 district hospitals (DHs), 388 comprehensive health centers (CHCs), 468 health sub-centers (HSCs), 34 mobile health teams (MHTs), 807 basic health centers (BHCs), and 10,277 health posts (HPs). Health outcomes have also shown notable improvements: under-five mortality rates have fallen from 172/1000 live births to 97/1,000 live births; maternal mortality rates have witnessed a sizable decline to 327/100,000 live births; and DPT3 immunization coverage has more than doubled from 30 percent to 66 percent. Despite this progress, an unparalleled 59 percent of children still suffer from stunting; and one in ten children dies of malnutrition before the age of five. Diarrheal disease rates and acute respiratory infection rates are amongst the highest in the world while acute respiratory infections is the major cause of mortality among children under 5 . As of 2012, Afghanistan is one of only three countries which remain polio-endemic.

Substantial morbidity gaps continue to exist between urban and rural locations, posing a severe problem given that Afghanistan's population is around 78 percent rural. Insecurity and geographic remoteness render many health care facilities inaccessible to both individuals and health workers; and the absence of skilled female personnel in health service provision is a major constraint to improving health. Resource constraints serve to exacerbate this situation. Afghanistan's per capita expenditure on health in 2008 was USD 42; of this amount, the government's contribution per capita was around USD 3. Not only is per capita expenditure on health the lowest amongst its neighbors and income peers, but Afghanistan is second only to Pakistan as the country with the lowest government contribution to health as a share of total government expenditures.

\section{Revisions To The Package:-}

Recognizing changing health needs and priorities and the importance of addressing some of the aforementioned challenges, the BPHS underwent a series of revisions in 2010. Most notably, the "new" package has:

Introduced primary eye care; increased investments in mental health and disability programs including the addition of physiotherapists and psychological counselors at district hospitals 
Integrated two new facilities into the system: health sub-centers and mobile health teams and Modified the list of essential medicines In line with new National Salary Policy regulations, salaries of BPHS staff have also been increased. The target is to increase BPHS coverage to 95 percent of the population by 2015 .

The BPHS is currently complemented by the Essential Package of Hospital Services (EPHS), which defines the essential elements of hospital services. The importance of developing stronger linkages across the two packages and a robust health referral system that integrates BPHS with hospital cannot be understated.

Afghanistan has a total population of 25.9 Million (CSO) of which only $22 \%$ is urban population. The remaining 78 $\%$ of the population lives in scattered rural areas. Life expectancy at birth is 45 years for women and 47 for men (Afghanistan Health Indicators, Fact Sheet). The under one and five mortality rate are 113/1000 and 257/1000 live births (MICS, 2003), and maternal mortality ratio is 1600/100000 live births (Bartlett, 2002). Whilst acute malnutrition is considered relatively low, chronic malnutrition in terms of prevalence rates of underweight children and stunting is estimated $40 \%$ and 54\% respectively (ANDS 2007). With a current GDP per capita of USD 329, the total public health expenditure as percentage of GDP accounts for $3 \%$ of the overall operating budget and 5\% of the development budget (ANDS, 2007).

Afghanistan consists of 34 province and twelve ethnic groups, Pashtons (40\%) and Tajiks (25\%) are the dominant ones. More than $50 \%$ of the population speaks Dari (Persian) and 35\% speaks Pashto. The majority of the population (84\%) are Sunni Muslim and 15\% are Shi'a Muslim.

In the last 3 decades Afghanistan has endured some of the roughest times of its history. In 1978 the communist regime took the power, leading to an invasion of the former Soviet Union military troops. It was the beginning of the conflict, insecurity, instability and severe war in Afghanistan. The Communist regime remained in power until 1992, and during the 13 years of its ruling it hardly contributed to the welfare of the people due to the war economy and the fight against the Mujahedeen, the freedom fighters.

After taking the power in 1992, a coalition of Mujahedeen factions brought Afghanistan into a new time of conflict , this time a civil war and inter-Mujahedeen fighting, which went on until 1996.

The Taliban ruled the country from 1996 to November 2001. "The Taliban showed little interest in the health sector, apart from enforcing strict gender segregation, which further impeded access to health services for women." (Sondorp, 2004). In December 2001, the Taliban regime collapsed and a new democratic government was established.

In 2002, the level of health services was shocking. Unavailability of a policy framework, inequalities in health service provision across the country, low capacity of public and private sectors, shortage of health human resources, differences in the quality of the services, the absence of infrastructure, and lack of coordination were overriding the situation (Waldman. et al., 2006).

Soon after the collapse of the Taliban regime and the establishment of the new government, the Ministry of Health of Afghanistan identified its major needs to address the most urgent problems. Hence, a basic package of health services (BPHS) was developed in March 2003. The key components of the BPHS focused on services that tackled the major health problems- services that were cost-effective and that could be equally accessed by both rural and urban populations. The BPHS offered four types of health services: health posts, basic health centers, comprehensive health centers, and district hospitals (BPHS 2003).

Health Posts (HP) are the smallest peripheral health units which deliver very limited services performed by community health workers (CHWs) from their own homes. A health post is staffed by one female and one male volunteer $\mathrm{CHW}$. It covers a population of 1,000 to 1,500 people. Health posts offer very basic health care including diagnosis and treatment of acute respiratory infections, malaria, and diarrhea. CHWs distribute condoms, oral contraceptives, and depot progesterone (DMPA) injections. Female $\mathrm{CHW}$ act as midwives in normal deliveries, identify danger signs, and referring complicated pregnancy cases to upper levels (BPHS 2010).

Basic Health Centers (BHC) offer antenatal, delivery, and postpartum care; family planning; routine immunization; IMCI; treatment of malaria and tuberculosis; including DOTS; and identification, referral, and follow-up care for 
mental patients and the disabled. Each BHC covers a population of 15,000-30,000. The BHC is staffed by a nurse or possibly a physician, a community midwife, two vaccinators and a community health supervisor (BPHS 2010).

In addition to the services provided by BHCs, comprehensive health centers (CHC) can manage some complicated cases like severe childhood illness and treatment for complex cases of malaria. Each CHC is staffed by both male and female doctors, male and female nurses, two community midwives, laboratory and pharmacy technicians and a community health supervisor. It covers a population of 30,000 to 60,000 people (BPHS 2010).

The District Hospital (DH) is the largest health unit in the BPHS level which manages most of referred and difficult cases. The district hospital provides all services in the BPHS such as maternal and new born health; child health and immunization; public nutrition; communicable diseases control; mental health; disability; and supply of essential drugs at the district level. The DH is staffed by two male and two female physicians (obstetrician/ gynecologist), surgeon, anesthetist, pediatrician; midwives; laboratory and X-ray technicians; pharmacist; dentist and dental technician. It covers a population of 100,000 to 300,000 people (BPHS 2005).

In March 2002, a joint donor mission consisting of representatives from international donors and UN agencies visited Afghanistan. One of the aims of the mission was to establish a framework for assistance to the health sector over the next years. The Ministry of Health and the mission agreed on contracting mechanisms to have NGOs providing health services in rural areas (World Bank, April 2002).

Three major donors - European Commission, USAID, World Bank - have funded all major programs through different types of contracting approaches including performance-based partnership agreements (Strong. et al, 2004). Hence, through contracting mechanisms with NGOs there has been an expansion of health service provision across the country. Shortly after its implementation the number of Afghan population that benefited from the BPHS increased from 9 to $85 \%$ (ANDS 2007).

Given that the BPHS is funded by donors, understanding the cost drivers of BPHS is essential for future planning. This study will focus on cost analysis of major drivers of BPHS in one province, Bamyan. The results will help understand the overall costing situation of BPHS in other province with similar context.

Bamyan is located in central part of Afghanistan, Bamyan is one of the poorest, most mountainous, and agriculturally least productive areas in the country. Much of the land is barren and inaccessible, with acute water shortages, small landholdings, extensive food insecurity, and poor soil quality characterizing much of the region. While specific communities in Bamyan have benefited from short-term relief efforts and some infrastructure improvements, substantial need for well-planned initiatives remains.

Literacy rates in Bamyan are low, ranging from 0.5\%, in districts such as Saighan, to 6\% in Bamyan centre for women and 6\% in Saighan, to 31\% in Bamyan centre for men according to a UNAMA/ Solidarities survey. Labour in Bamyan is generally unskilled and the low capacity of the Bamyan workforce is hampering the possibilities for economic development in the province. Regional Rural Economic Regeneration Strategies (RRERS) GRM 2 of 8 Years of conflict and drought resulted in substantial population movements both within and out of the province. Though returnees have come to Bamyan, the scarcity of land and lack of economic opportunity reduces the incentives for people to settle in the province. These same trends encourage migration out of the province. Seasonal migration is particularly prevalent when, during the winter, many from Bamyan travel to the main cities in Afghanistan. There is currently little movement within the province as Bamyan centre does not offer the economic opportunities to encourage this trend.

Most of Bamyan's schools were either destroyed during the war or were never there due to the discrimination Hazara's faced from the central governments in the past. Many of these are being rehabilitated through support from the international aid agencies. Education for the girl child seems to be well supported by the community and one can see everywhere girls going to school, even where they have to walk for one hour each way. But slightly older girls, even 12-13 year olds, tend to drop out under community/family pressure if the distance to the schools is far. An associated problem has been the disruption of schooling for many during the war and as peace sets in, this has resulted in increasing demand for non-formal education. 
The other big problem in Bamyan is the lack of sufficiently educated and skilled teachers. It is difficult to find a teacher with grade 12th education themselves, most are around the grade 8 th. This problem is more acute in case of women teachers. Programs for upgrading the skills of teachers, both methodological as well as subject knowledge. For regular teacher training, etc are much needed.

There is severe paucity of technical and higher skilled people in Bamyan. Those who have them have migrated out of the country or live and work in Mazar and Kabul and are not interested in coming back given the infrastructure and facilities in Bamyan. This represents one of the most fundamental hindrance to long term development in the province. There is need to build capacity around applied skills that can allow people to find employment and take the process of development forward. Similar situation prevails within the government and capacity building on various fronts is a key.

Table 3:- Summary Of Bphs Services And Staffing By Facility

\begin{tabular}{|c|c|c|c|c|}
\hline Facility Type & $\begin{array}{l}\text { Catchment } \\
\text { Population }\end{array}$ & Services/Procedures Offered & Staffing & \\
\hline $\begin{array}{l}\text { District } \\
\text { Hospitals }\end{array}$ & $\begin{array}{l}100,000- \\
300,000\end{array}$ & $\begin{array}{l}\text { All services offered by comprehensive } \\
\text { health centers and: } \\
\text { Maternal and Newborn Health } \\
\text { (comprehensive emergency obstetric care, } \\
\text { male and female sterilization) } \\
\text { Communicable Diseases (x-ray for smear- } \\
\text { negative patients, short-term chemotherapy, } \\
\text { preventive therapy for children contacts of } \\
\text { TB patients) } \\
\text { Mental Health (occupational and speech } \\
\text { therapy, psychosocial counselling, training, } \\
\text { and supervision in mental health, and } \\
\text { psychosocial support for staff of CHC and } \\
\text { BHC) }\end{array}$ & $\begin{array}{l}\text { Male physician } \\
\text { Female physician } \\
\text { (ob/gyn) } \\
\text { Surgeon } \\
\text { Anaesthetist } \\
\text { Nurse (male or } \\
\text { female) } \\
\text { Mid-wife }\end{array}$ & $\begin{array}{l}\text { Physiotherapist } \\
\text { X-ray } \\
\text { technician } \\
\text { Lab technician } \\
\text { Pharmacist } \\
\text { Dentist } \\
\text { Dentist } \\
\text { technician } \\
\text { Vaccinator }\end{array}$ \\
\hline $\begin{array}{l}\text { Comprehensive } \\
\text { Health Centers }\end{array}$ & $\begin{array}{l}30,000- \\
60,000\end{array}$ & $\begin{array}{l}\text { All services offered by basic health centers } \\
\text { and: } \\
\text { Maternal and Newborn Health (care of } \\
\text { newborn, basic emergency obstetric care, } \\
\text { manage neonatal infections and sepsis, } \\
\text { distribute progesterone injection and IUD) } \\
\text { Child Health and Immunization (EPI } \\
\text { services) } \\
\text { Disability (inpatient and outpatient } \\
\text { physiotherapy, orthopedics diagnosis) }\end{array}$ & $\begin{array}{l}\text { Male physician } \\
\text { Female physician } \\
\text { Nurse (male) } \\
\text { Nurse (female) } \\
\text { Mid-wife }\end{array}$ & $\begin{array}{l}\text { Psychosocial } \\
\text { counsellor } \\
\text { Lab technician } \\
\text { Pharmacy } \\
\text { technician } \\
\text { Vaccinator }\end{array}$ \\
\hline $\begin{array}{l}\text { Mobile Health } \\
\text { Teams }\end{array}$ & Varies & $\begin{array}{l}\text { Mobile health services are an extension of } \\
\text { basic health center services; therefore, the } \\
\text { services they provide are in most cases } \\
\text { those recommended for a basic health } \\
\text { center }\end{array}$ & $\begin{array}{l}\text { Doctor/Nurse } \\
\text { (male) } \\
\text { Community }\end{array}$ & $\begin{array}{l}\text { Midwife/Nurse } \\
\text { (female) } \\
\text { Vaccinator }\end{array}$ \\
\hline $\begin{array}{l}\text { Basic Health } \\
\text { Center }\end{array}$ & $\begin{array}{l}15,000- \\
30,000\end{array}$ & $\begin{array}{l}\text { All services offered by sub-health centers } \\
\text { and: } \\
\text { Maternal and Newborn Health (STD } \\
\text { screening and treatment) } \\
\text { Public Nutrition (growth monitoring) } \\
\text { Communicable Diseases (short-term } \\
\text { chemotherapy) } \\
\text { Disability (refer for fitting and training of } \\
\text { orthesis and prosthesis) }\end{array}$ & $\begin{array}{l}\text { Nurse (male) } \\
\text { Midwife/Auxiliary } \\
\text { Midwife } \\
\text { Vaccinator }\end{array}$ & \\
\hline $\begin{array}{l}\text { Health Sub- } \\
\text { center }\end{array}$ & $\begin{array}{l}3,000- \\
7,000\end{array}$ & $\begin{array}{l}\text { All services offered by health-posts and: } \\
\text { Maternal and Newborn Health (STD }\end{array}$ & $\begin{array}{l}\text { Male nurse } \\
\text { Community }\end{array}$ & \\
\hline
\end{tabular}




\begin{tabular}{|c|c|c|c|}
\hline & & $\begin{array}{l}\text { treatment) } \\
\text { Communicable Diseases (TB case } \\
\text { detection) } \\
\text { Child Health and Immunization (case } \\
\text { management of ARI, fever/malaria; refer } \\
\text { complicated cases) }\end{array}$ & wife \\
\hline $\begin{array}{l}\text { Health Post } \\
\text { (usually } \\
\text { services } \\
\text { provided from } \\
\text { community } \\
\text { health worker's } \\
\text { home) }\end{array}$ & $\begin{array}{l}1,000- \\
1,500\end{array}$ & 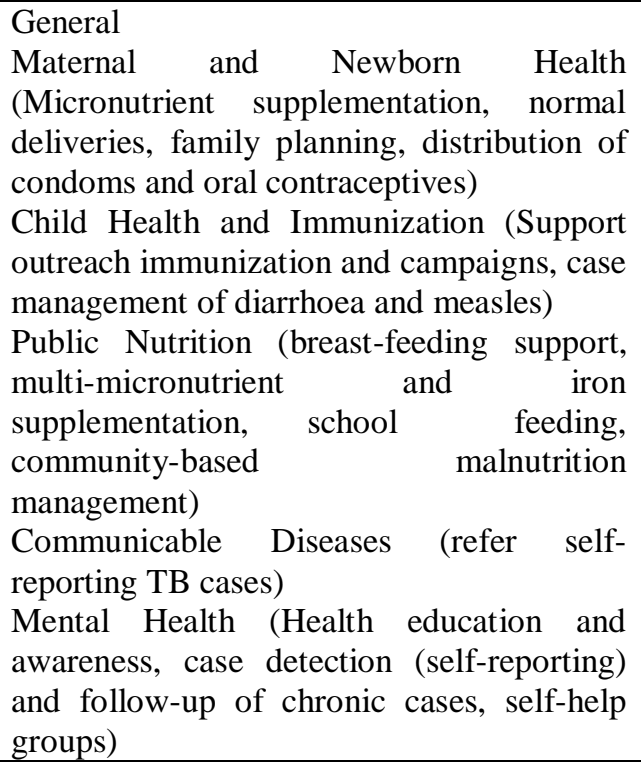 & $\begin{array}{l}1 \text { Male } \\
\text { Community } \\
\text { Health Worker } \\
1 \quad \text { Female } \\
\text { Community } \\
\text { Health Worker }\end{array}$ \\
\hline
\end{tabular}

\section{Objectives Of The Bphs Costing Exercise:-}

The primary goal of this study is to model the costs and funding requirements of the BPHS in light of revisions to the package. The estimates are intended to support planning and implementation, as well as to assist in the preparation of county-level service delivery plans and budgets. They should also assist the MoPH in coordinating and harmonizing external assistance. More specific objectives, in line with Afghanistan's National Health and Nutrition Policy 2012 - 2020 include:

Understanding major BPHS cost drivers Comparing cost variations across facilities and province and linking these to differences in service delivery and contracting mechanisms Informing decisions about resource allocations across primary health care facilities; and potential areas where additional resources/subsidies may be required

This report examines the period covering June 1, 2015 - May 31, 2016.

\section{Organization Of This Report:-}

This report is organized into four sections:

Section 1 provides background information on the BPHS and the purposes of this exercise.

Section 2 describes the methodology used for this costing exercise.

Section 3 presents general findings.

Section 4 provides discussion and conclusions.

Methodology:-

Type of study will be Cohort Study and using data in this study compiled from June 1st, 2015 - May31, 2016.

\section{Overview Of Approach:-}

Healthcare access, quality and outcomes vary widely across geographies in Afghanistan. Variations in the financing and provision of health care services along with ongoing security concerns, population displacements, geographic remoteness, socio-cultural isolation, and health awareness contribute to these differences. This presents significant challenges in using sample data to make generalizations to the entire population. To address this, we have carefully selected province for inclusion in our sample to achieve good geographic spread and sufficient representation from each district. 


\section{Sampling And Selection:-}

In the first stage of selection, Bamyan Province was evaluated based on the following criteria:

Geographical representation (Central, North, South, West)

Population representativeness

Donor-funded (WB)

National NGO

Given the limited resource, only one province out of 31 province is selected randomly.

Data from all 49 BPHS facilities in the sampled province have been included in the exercise. The sample represents approximately ( $3 \%$ ) of all BPHS health facilities and covers ( around 2\%) of the total population in Afghanistan.

\section{Data Collection:-}

Data Sources:-

Health facility data was collected from the implementing organizations MOVE Welfare Organization and Bu Ali Rehabilitation \& Aid Network (BARAN)

A data collection tool developed to facilitate data collection.

\section{Cost Inputs:- \\ Direct Costs:-}

To calculate the direct operating expenditures for each BPHS facility, the resources used exclusively by the facility were defined:

Salaries and wages include the base salary and any series of bonuses and allowances as applicable (overtime allowances, working conditions allowances, travel allowances)

Drugs and disposables include the direct costs of drugs, disposables (gloves, sutures), medical supplies and medical tests (laboratory, $\mathrm{x}$ - ray, ultra-sonogram, and other medical tests)

Training and development include all training, education, and staff development costs and associated expenses related to travel and course materials

Other operational expenses include utilities (electricity, water, and gas consumption costs), communication (telephone, fax, internet, and postage), office supplies, housekeeping, security, laundry, kitchen (food for patients and staff), maintenance (building, equipment and furniture, vehicles), accounting and audit, insurance and legal fees, and travel expenses

Capital expenses include capital resources, equipment, and furniture for each facility.

\section{Indirect Costs:-}

To calculate the indirect operating costs for comprehensive health centers, the total number of outpatient visits across all facilities was measured and then allocated to each facility based on its workload).

\section{Assumptions:-}

A number of assumptions underlie the analysis:

Comprehensive health centers that do not indicate a location are considered "rural" in order to reduce the impact of missing values

For the purposes of this analysis, upgraded comprehensive health centers (CHC+) have been merged with $\mathrm{CHCs}$

\section{Data Validation:-}

Because the data collected from implementer NGOs is secondary in nature, it was validated using other related records when made available. These include general ledgers, receipts, and inventory records. Questionable and inconsistent data provided by NGO representatives were also verified with NGO manager.

\section{Data Analysis:-}

The analysis serves two purposes:

Uncover the overall operating costs of BPHS in the sampled province using the cost inputs in 2.3.2; and Identify variations in operating costs across different facility types.

To better reflect on the differences of cost items across parameters, in some cases median values are presented alongside mean values. In addition statistical analyses were conducted to evaluate how significant are the differences in the operating costs between the health facilities and across the rural/urban areas. One-way ANOVA was conducted to compare the costs between the health facilities, the locations (rural, urban, etc.) and the geographical clusters (North, South, etc.). Correlation studies enabled the identification of explanatory variables for 
costs variations given different independent variables or parameters. Multivariate regression analyses were conducted to estimate the percentage of variance in the dependent variable explained collectively by all the independent variables identified in the correlation study. Hence, the multivariate regression analysis indicates the impact of the changes in a particular cost parameter on the direction and the magnitude of the variation in other parameters. Finally, as a data mining approach, Pearson hierarchical clustering was performed to uncover spending patterns and trends in the utilization of resources with respect to the selected health facilities, rural/urban areas.

\section{General Findings:-}

\section{Summary of Findings:-}

\section{Overall Costs:-}

In 2014 - 2015, total BPHS operating costs across 49 BPHS sample health facilities in Bamyan province were USD 2,342,479,. This represented an average per capita cost of USD 6, ranging from USD 19.7 (District Hospital) to USD 6 (Comprehensive Health Center) to USD 3(Basic Health Center) and to USD 4 (Sub Health Center). The differences in BPHS costs across the Health Facilities were significant $(\mathrm{p}<0.001$,). Of the sampled health facilities, at over USD 2322479, BPHS total operating costs were on average the highest in district hospital, Panjab, Waras and Yakawalang districts followed with an average total costs over USD 500,000. Kahmard, Bamyan, Saighan, Waras were the districts with the lowest expenditure. This repartition of the costs did correlate neither with the geographical district nor with the population size of the selected health facilities, suggesting some particularities in the management and the utilization of resources. Table 5 summarizes the total BPHS health facilities by districts.

Table 4:- Number of facilities sampled across districts:

\begin{tabular}{|l|l|l|l|l|l|l|}
\hline HFs & Bamyan & Kahmard & Panjab & Saighan & Waras & Yakawalang \\
\hline HSC & 3 & 0 & 4 & 0 & 7 & 4 \\
\hline BHC & 1 & 3 & 4 & 2 & 5 & 3 \\
\hline CHC & 3 & 1 & 1 & 1 & 1 & 3 \\
\hline DH & 0 & 0 & 1 & 0 & 1 & 1 \\
\hline
\end{tabular}

Salaries and wages comprise the largest share of BPHS costs (52 percent) followed by other operational expenses (31percent) and drugs and disposables (17 percent). If we exclude depreciation on capital expenditures, expenditures related to training and development represented the smallest share of expenditures of about xxx percent. Table 7 shows the breakdown of operating costs by facility across rural and urban locations.

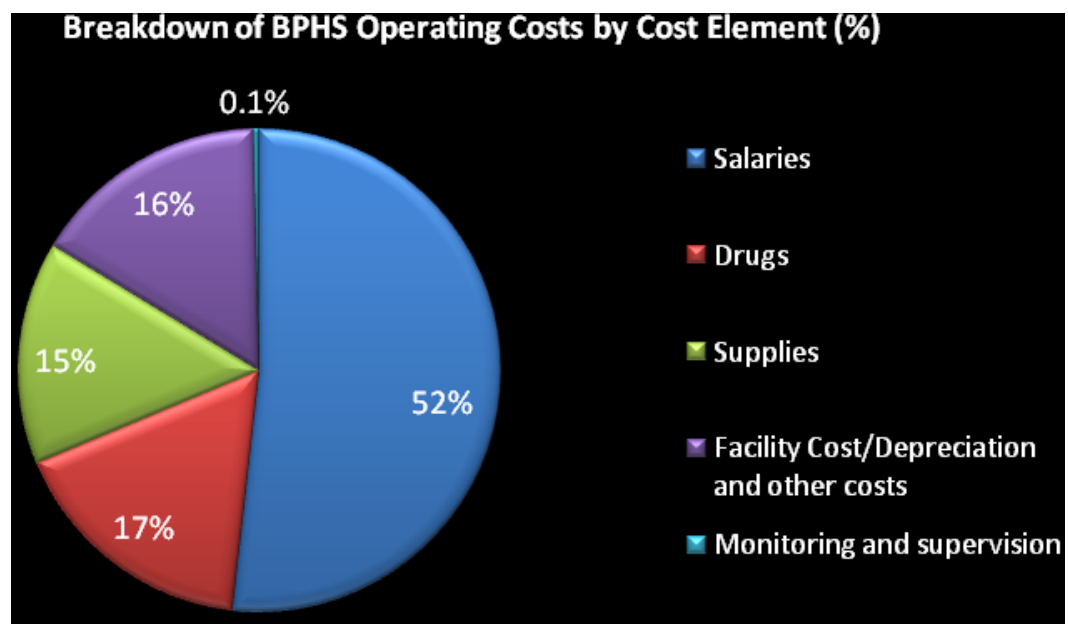

To further identify the costs drivers in each of the selected district, all the data were mean centered and clustered using a Pearson correlation as a similarity metric and average linkage hierarchical district wise. 
Table 5:- Breakdown of BPHS operating Cost by Cost Elements. By Facility and Across Rural/ Urban Areas

\begin{tabular}{|l|l|l|l|l|l|}
\hline & $\begin{array}{l}\text { Cost of Salary } \\
\text { Wages }\end{array}$ & $\begin{array}{l}\text { Cost of } \\
\text { Drugs }\end{array}$ & $\begin{array}{l}\text { Supplie } \\
\text { s }\end{array}$ & $\begin{array}{l}\text { Facility } \\
\text { Costs/Depreciation }\end{array}$ & $\begin{array}{l}\text { Monitoring } \\
\text { supervision }\end{array}$ \\
\hline SHC & & & & & $14 \%$ \\
\hline Rural & $50 \%$ & $18 \%$ & $15 \%$ & $3.30 \%$ & $0.1 \%$ \\
\hline $\begin{array}{l}\text { Isolated } \\
\text { Rural }\end{array}$ & $96 \%$ & $0.3 \%$ & $1 \%$ & $3 \%$ & $5.2 \%$ \\
\hline Deep Rural & $84 \%$ & $4.6 \%$ & $4 \%$ & $2 \%$ & \\
\hline BHC & & & & & $17 \%$ \\
\hline Rural & $39 \%$ & $24 \%$ & $18 \%$ & $2 \%$ & $23.3 \%$ \\
\hline $\begin{array}{l}\text { Isolated } \\
\text { Rural }\end{array}$ & $0 \%$ & $26.4 \%$ & $50 \%$ & $0.17 \%$ & $17.0 \%$ \\
\hline Deep Rural & $65 \%$ & $8.6 \%$ & $8 \%$ & $2 \%$ & $16.5 \%$ \\
\hline CHC & & & & & $3 \%$ \\
\hline Rural & $33 \%$ & $25.7 \%$ & $24 \%$ & $0.51 \%$ & $10 \%$ \\
\hline $\begin{array}{l}\text { Isolated } \\
\text { Rural }\end{array}$ & $73 \%$ & $7 \%$ & $12 \%$ & $5 \%$ & $15 \%$ \\
\hline Deep Rural & $57 \%$ & $13 \%$ & $15 \%$ & $5 \%$ & \\
\hline DH & & & & & \\
\hline Deep Rural & $59 \%$ & $8 \%$ & $14 \%$ & $4 \%$ & \\
\hline
\end{tabular}

Total Bphs Operational Costs:-

Total operational costs include salaries and wages; drugs and disposables; governance, supervision, and monitoring, capital expenditures, and other operational expenses. Overall, the geographical clusters showed specificities in their expenditures profiles these discrepancies were reflected at the level of the facilities and of the rural/urban areas. Bellow table provides a complete breakdown of the total BPHS operating costs by geographical cluster and by location.

Table 6:- Summary of Total Costs by Facility Across Rural and Urban Locations

\begin{tabular}{|l|l|l|l|l|l|l|l|}
\hline & & Rural & \multicolumn{2}{l|}{ Isolated Rural } & \multicolumn{2}{l|}{ Deep Rural } \\
\hline Health Facilities & Parameters & AFG & USD & AFG & USD & AFG & USD \\
\hline SHC & Mean & 846045 & 16920.9 & 848084 & 16961.68 & 306487 & 6129.74 \\
\hline & Median & 902587 & 18051.74 & 850426 & 17008.52 & 784610 & 15692.2 \\
\hline BHC & Mean & 848110 & 16962.2 & - & - & 1486835 & 29736.7 \\
\hline & Median & 1505235 & 30104.7 & - & - & 1534742 & 30694.84 \\
\hline CHC & Mean & 3607975 & 72159.5 & - & - & 3639263 & 72785.26 \\
\hline & Median & 3465902 & 69318.04 & - & - & 3610061 & 72201.22 \\
\hline
\end{tabular}

Health sub-centers: There was a significant difference in the operating costs across the districts $(\mathrm{p}<0.001)$. The Waras, Yakawalang and Saighan districts showed the highest average expenditures costs, the Bamyan and Panjab districts being the less resource consuming district

Basic health centers: Substantial differences between the geographical districts were detected $(\mathrm{p}<0.001)$. The Waras and Panjab districts were, on average, the most costly clusters. The Bamyan and Saighan districs had basic expenditures.

Comprehensive health centers: The differences in costs were also significant between the geographical clusters $(\mathrm{p}<0.001)$. The Bamyan and Yakawalang districts were on average the most costly clusters. The Saighan district showed on average, the lowest expenditures costs.

District hospitals: Significant differences in the geographical clusters' expenditures were noticed $(\mathrm{p}<0.05)$. The Waras district showed the lowest average costs. By Yakawalang, average costs were the highest in the Waras district. 
Salaries And Wages:-

Salaries and wages include both base salaries as well as performance incentives, bonuses, and security allowances (usually provided to keep insecure facilities appropriately staffed). Correlation analyses showed a positive and strong relationship between the variations in salaries and wages and the type of facility. Table below provides a complete breakdown of salaries and wages for each health facility.

Health sub-centers: The costs of the staff varied significantly across the geographical districts ( $<<0.001)$. Waras and Yakawalang districts were, on average, the most expensive in term of salaries and Bamyan and Panjab districts had the lowest salaries. Overall, there was a reduction in salaries and wages compared to the provincial average in both Bamyan and Panjab. The largest increased were in the Waras district about 7\% of provincial average.

Basic health centers: Changes in salaries and wages were also significant $(\mathrm{p}<0.001)$. Salaries were on average the highest in Waras and Panjab districts and the lowest in the Bamyan distric. Whatever Bamyan and Saighan districts were lowest to the provincial average in terms of salaries and wages. The largest reductions from the national average were in the Bamyan and Saighan districts (reduction by 71 and 51 percent, respectively).

Comprehensive health centers: Salaries and wages differed significantly between the geographical clusters $(\mathrm{p}<0.05)$. Yakawalang and Bamyan districts were the most expensive districts, the Panjab district, and the least costly one. Salaries in almost all districts except Yakawalang and Bamyan districs decreased compared the provincial average.

District hospitals: Though significant difference in salaries and wages were observed $(\mathrm{p}<0.001)$, Waras is the highest and Panjab is the lowest districts in terms of salaries and wages, there was an overall increase from the national average in the staff costs of Waras and Yakawalang.

Table 7:- Salaries and Wages by Facility Across Districts Rural/Urban Areas

\begin{tabular}{|c|c|c|c|c|c|c|c|c|c|c|c|c|}
\hline \multirow{2}{*}{$\begin{array}{l}\text { HFs by } \\
\text { geography }\end{array}$} & \multicolumn{2}{|c|}{ Yakawalang } & \multicolumn{2}{|l|}{ Waras } & \multicolumn{2}{|l|}{ Panjab } & \multicolumn{2}{|c|}{ Bamyan } & \multicolumn{2}{|c|}{ Kahmard } & \multicolumn{2}{|c|}{ Saighan } \\
\hline & AFA & USD & AFA & USD & AFA & USD & AFA & USD & AFA & $\begin{array}{l}\text { US } \\
\text { D }\end{array}$ & AFA & $\begin{array}{l}\text { US } \\
\text { D }\end{array}$ \\
\hline \multicolumn{13}{|l|}{ SHC } \\
\hline Rural & $\begin{array}{l}45600 \\
0\end{array}$ & 9120 & 0 & 0 & 0 & 0 & $\begin{array}{l}14778 \\
96\end{array}$ & $\begin{array}{l}2955 \\
8\end{array}$ & 0 & 0 & 0 & 0 \\
\hline $\begin{array}{l}\text { Isolated } \\
\text { Rural }\end{array}$ & & 0 & $\begin{array}{l}13581 \\
00\end{array}$ & $\begin{array}{l}2716 \\
2\end{array}$ & 74345 & 1487 & 0 & 0 & 0 & 0 & 0 & 0 \\
\hline Dep Rural & $\begin{array}{l}17559 \\
00\end{array}$ & $\begin{array}{l}3511 \\
8\end{array}$ & $\begin{array}{l}98958 \\
0\end{array}$ & $\begin{array}{l}1979 \\
2\end{array}$ & $\begin{array}{l}22303 \\
5 \\
\end{array}$ & 4461 & 0 & 0 & 0 & 0 & 0 & 0 \\
\hline & $\begin{array}{l}22119 \\
00\end{array}$ & $\begin{array}{l}4423 \\
8\end{array}$ & & $\begin{array}{l}4695 \\
4\end{array}$ & & & $\begin{array}{l}14778 \\
96\end{array}$ & $\begin{array}{l}2955 \\
8\end{array}$ & 0 & 0 & 0 & 0 \\
\hline \multicolumn{13}{|l|}{ BHC } \\
\hline Rural & $\begin{array}{l}17259 \\
52\end{array}$ & $\begin{array}{l}3451 \\
9\end{array}$ & $\begin{array}{l}93317 \\
8\end{array}$ & $\begin{array}{l}1866 \\
4\end{array}$ & $\begin{array}{l}23329 \\
4\end{array}$ & 4666 & $\begin{array}{l}62608 \\
8\end{array}$ & $\begin{array}{l}1252 \\
2\end{array}$ & $\begin{array}{l}14820 \\
00\end{array}$ & $\begin{array}{l}296 \\
40\end{array}$ & $\begin{array}{l}48220 \\
0\end{array}$ & $\begin{array}{l}964 \\
4\end{array}$ \\
\hline Dep Rural & $\begin{array}{l}50828 \\
4\end{array}$ & $\begin{array}{l}1016 \\
6\end{array}$ & $\begin{array}{l}23329 \\
4\end{array}$ & 4666 & $\begin{array}{l}69988 \\
3 \\
\end{array}$ & 13998 & 0 & 0 & $\begin{array}{l}53544 \\
0\end{array}$ & $\begin{array}{l}107 \\
09\end{array}$ & $\begin{array}{l}59234 \\
4 \\
\end{array}$ & $\begin{array}{l}118 \\
47\end{array}$ \\
\hline & $\begin{array}{l}22342 \\
36 \\
\end{array}$ & $\begin{array}{l}4468 \\
5 \\
\end{array}$ & $\begin{array}{l}11664 \\
72\end{array}$ & $\begin{array}{l}2332 \\
9\end{array}$ & $\begin{array}{l}93317 \\
7\end{array}$ & 18664 & $\begin{array}{l}62608 \\
8\end{array}$ & $\begin{array}{l}1252 \\
2\end{array}$ & $\begin{array}{l}20174 \\
40\end{array}$ & $\begin{array}{l}403 \\
49\end{array}$ & $\begin{array}{l}10745 \\
44\end{array}$ & $\begin{array}{l}214 \\
91\end{array}$ \\
\hline \multicolumn{13}{|l|}{ CHC } \\
\hline Rural & $\begin{array}{l}55831 \\
08\end{array}$ & $\begin{array}{l}1116 \\
62\end{array}$ & $\begin{array}{l}23758 \\
74\end{array}$ & $\begin{array}{l}4751 \\
7\end{array}$ & 0 & 0 & $\begin{array}{l}51541 \\
66\end{array}$ & $\begin{array}{l}1030 \\
83\end{array}$ & $\begin{array}{l}24773 \\
16\end{array}$ & $\begin{array}{l}495 \\
46\end{array}$ & $\begin{array}{l}22762 \\
32\end{array}$ & $\begin{array}{l}455 \\
25\end{array}$ \\
\hline $\begin{array}{l}\text { Isolated } \\
\text { Rural }\end{array}$ & 0 & 0 & 0 & 0 & 0 & 0 & 0 & 0 & 0 & 0 & 0 & 0 \\
\hline $\begin{array}{l}\text { Deep } \\
\text { Rural } \\
\end{array}$ & 0 & 0 & 0 & 0 & $\begin{array}{l}17196 \\
95\end{array}$ & 34394 & 0 & 0 & 0 & 0 & 0 & 0 \\
\hline & $\begin{array}{l}55831 \\
08\end{array}$ & $\begin{array}{l}1116 \\
62\end{array}$ & $\begin{array}{l}23758 \\
74\end{array}$ & $\begin{array}{l}4751 \\
7\end{array}$ & $\begin{array}{l}17196 \\
95\end{array}$ & 34394 & $\begin{array}{l}51541 \\
66\end{array}$ & $\begin{array}{l}1030 \\
83\end{array}$ & $\begin{array}{l}24773 \\
16\end{array}$ & $\begin{array}{l}495 \\
46\end{array}$ & $\begin{array}{l}22762 \\
32\end{array}$ & $\begin{array}{l}455 \\
25\end{array}$ \\
\hline \multicolumn{13}{|l|}{ DH } \\
\hline Dep Rural & 68501 & 1370 & 59099 & 1181 & 24684 & 49368. & 0 & 0 & 0 & 0 & 0 & 0 \\
\hline
\end{tabular}




\begin{tabular}{|l|l|l|l|l|l|l|l|l|l|l|l|l|}
\hline & 60 & 03 & 56 & 99 & 12 & 24 & & & & & & \\
\hline & 68501 & 2486 & 59099 & 1657 & 24684 & 83762 & 0 & 0 & 0 & 0 & 0 & 0 \\
& 60 & 65 & 56 & 17 & 12 & & & & & & & \\
\hline
\end{tabular}

Drugs And Disposables:-

Drugs and disposables are procured or received centrally by NGOs from a national Essential Drugs List and then distributed among respective health facilities across the province in which these NGOs operate. Correlation analyses showed a moderate and positive association between the variations in drugs and disposables expenditures and the facility types. Regression analyses indicated that $27 \%$ of the variation in drugs and disposables could be explained by the specificities of the health facilities. Table 10 provides a complete breakdown by geographical cluster and by location.

Health sub-centers: Substantial differences were detected between the districts $(\mathrm{p}<0.001)$. The Yakawalang and Panjab districts were, on average, the ones with the highest spending on drugs and disposables $(\mathrm{p}<0.001)$. The Bamyan and Waras districts had the least expenditures on drugs.

Basic health centers: As with the HSC facility, the Panjab, Yakawalang and Kahmard clusters had the greatest spending on drugs, the Waras and Bamyan districts the least one. These differences in average expenditures were significant $(\mathrm{p}<0.001)$.

Comprehensive health centers: Variations between the geographical districts were significant $(\mathrm{p}<0.001)$. On average, Yakawalang district had the highest expenditure on drugs, and Panjab district the least one.

District hospitals: Variation in drugs expenditures across the geographical districts were the same. Yakawalang, Panjab, and Waras were the districts with the most elevated spending on drugs. In mentioned districts, average drugs expenditures were higher to the provincial average.

Table 8:- Cost of Drugs supply per annum (AFA)

\begin{tabular}{|c|c|c|c|c|c|c|c|c|c|c|c|c|}
\hline \multirow{2}{*}{$\begin{array}{l}\text { HFs by } \\
\text { geography }\end{array}$} & \multicolumn{2}{|c|}{ Yakawalang } & \multicolumn{2}{|l|}{ Waras } & \multicolumn{2}{|l|}{ Panjab } & \multicolumn{2}{|c|}{ Bamyan } & \multicolumn{2}{|c|}{ Kahmard } & \multicolumn{2}{|c|}{ Saighan } \\
\hline & AFA & USD & AFA & USD & AFA & USD & AFA & USD & AFA & $\begin{array}{l}\text { US } \\
\text { D }\end{array}$ & AFA & $\begin{array}{l}\text { US } \\
\text { D }\end{array}$ \\
\hline \multicolumn{13}{|l|}{ SHC } \\
\hline Rural & $\begin{array}{l}14016 \\
1\end{array}$ & 2803 & $\begin{array}{l}14016 \\
1\end{array}$ & 2803 & 0 & 0 & $\begin{array}{l}42048 \\
4\end{array}$ & 8410 & 0 & 0 & 0 & 0 \\
\hline $\begin{array}{l}\text { Isolated } \\
\text { Rural }\end{array}$ & 0 & 0 & $\begin{array}{l}56064 \\
5\end{array}$ & $\begin{array}{l}1121 \\
3\end{array}$ & $\begin{array}{l}14016 \\
1\end{array}$ & 2803 & 0 & 0 & 0 & 0 & 0 & 0 \\
\hline \multirow[t]{2}{*}{ Deep Rural } & $\begin{array}{l}42048 \\
4\end{array}$ & 8410 & $\begin{array}{l}28032 \\
3 \\
\end{array}$ & 5606 & $\begin{array}{l}42048 \\
4 \\
\end{array}$ & 8410 & 0 & 0 & 0 & 0 & 0 & 0 \\
\hline & & $\begin{array}{l}1121 \\
3\end{array}$ & & $\begin{array}{l}1962 \\
3\end{array}$ & & & $\begin{array}{l}42048 \\
4\end{array}$ & 8410 & 0 & 0 & 0 & 0 \\
\hline \multicolumn{13}{|l|}{ BHC } \\
\hline Rural & $\begin{array}{l}29955 \\
6 \\
\end{array}$ & 5991 & $\begin{array}{l}14977 \\
8\end{array}$ & 2996 & $\begin{array}{l}44933 \\
3 \\
\end{array}$ & 8987 & $\begin{array}{l}14977 \\
8\end{array}$ & 2996 & $\begin{array}{l}2995 \\
56 \\
\end{array}$ & $\begin{array}{l}599 \\
1 \\
\end{array}$ & $\begin{array}{l}1497 \\
78\end{array}$ & $\begin{array}{l}299 \\
6 \\
\end{array}$ \\
\hline \multirow[t]{2}{*}{ Deep Rural } & $\begin{array}{l}14977 \\
8\end{array}$ & 2996 & $\begin{array}{l}14977 \\
8\end{array}$ & 2996 & $\begin{array}{l}14977 \\
8\end{array}$ & 2996 & 0 & 0 & $\begin{array}{l}1497 \\
78\end{array}$ & $\begin{array}{l}299 \\
6\end{array}$ & $\begin{array}{l}1497 \\
78\end{array}$ & $\begin{array}{l}299 \\
6\end{array}$ \\
\hline & $\begin{array}{l}44933 \\
4\end{array}$ & 8987 & $\begin{array}{l}29955 \\
6\end{array}$ & 5991 & $\begin{array}{l}59911 \\
1\end{array}$ & 11982 & $\begin{array}{l}14977 \\
8\end{array}$ & 2996 & $\begin{array}{l}4493 \\
34\end{array}$ & $\begin{array}{l}898 \\
7\end{array}$ & $\begin{array}{l}2995 \\
56\end{array}$ & $\begin{array}{l}599 \\
1\end{array}$ \\
\hline \multicolumn{13}{|l|}{$\mathrm{CHC}$} \\
\hline Rural & $\begin{array}{l}11332 \\
08\end{array}$ & $\begin{array}{l}2266 \\
4\end{array}$ & $\begin{array}{l}37773 \\
6\end{array}$ & 7555 & 0 & 0 & $\begin{array}{l}21017 \\
96\end{array}$ & $\begin{array}{l}4203 \\
6 \\
\end{array}$ & $\begin{array}{l}3777 \\
36 \\
\end{array}$ & $\begin{array}{l}755 \\
5 \\
\end{array}$ & $\begin{array}{l}3777 \\
36\end{array}$ & $\begin{array}{l}755 \\
5 \\
\end{array}$ \\
\hline $\begin{array}{l}\text { Isolated } \\
\text { Rural } \\
\end{array}$ & 0 & 0 & 0 & 0 & 0 & 0 & 0 & 0 & 0 & 0 & 0 & 0 \\
\hline Deep Rural & 0 & 0 & 0 & 0 & $\begin{array}{l}37773 \\
6\end{array}$ & 7555 & 0 & 0 & 0 & 0 & 0 & 0 \\
\hline & 11332 & 2266 & 37773 & 7555 & 37773 & 7555 & 21017 & 4203 & 3777 & 755 & 3777 & 755 \\
\hline
\end{tabular}




\begin{tabular}{|c|c|c|c|c|c|c|c|c|c|c|c|c|}
\hline & 08 & 4 & 6 & & 6 & & 96 & 6 & 36 & 5 & 36 & 5 \\
\hline \multicolumn{13}{|l|}{$\mathrm{DH}$} \\
\hline Deep Rural & $\begin{array}{l}24684 \\
12\end{array}$ & $\begin{array}{l}4936 \\
8\end{array}$ & $\begin{array}{l}24684 \\
12\end{array}$ & $\begin{array}{l}4936 \\
8\end{array}$ & $\begin{array}{l}24684 \\
12\end{array}$ & $\begin{array}{l}49368 . \\
24\end{array}$ & 0 & 0 & 0 & 0 & 0 & 0 \\
\hline
\end{tabular}

\section{Governance, Monitoring, And Supervision:-}

Governance, monitoring and supervision includes the costs related to finance and administration. Correlation analyses suggested that the types of health facility, the variations in salaries and wages and drugs and disposables could potentially explain the variations in governance and monitoring. This moderate and positive correlation was further confirmed with the regression analyses. Forty-five percent of the variation in governance and monitoring could be explained by the types of health facility, the variation in salaries and wages and the variations in drugs and disposables.

Health sub-centers: There were substantial differences in the governance costs between the districts ( $\mathrm{p}<0.001$ ). Waras and Yakawalang districts displayed the highest average costs, and the Panjab and Bamyan districts the lowest costs. From the provincial average, costs were reduced in Panjab district but increased in Waras district.

Basic health centers: Significant changes occurred between 6 districts of Bamyan province $(\mathrm{p}<0.001)$. Waras and Panjab districts were the most costly in term of governance expenditures. The Bamyan and Saighan districts showed the lowest average costs. Overall, costs were increase in Waras, Panjab and Yakawalang districts and reduced in Bamyan, Saighan and Kahmard compared to the Provincial average.

Comprehensive health centers: Substantial differences in the governance costs between the geographical districts were significant $(\mathrm{p}<0.001)$. Bamyan and Yakawalang districts had the highest expenditure on Governance, Monitoring and Supervision, Panjab and Saighan districts are the least one. Among the provincial average Panjab, Saighan, Waras and Kahmard showed decrease and Bamyan and Yakawalang showed increment.

District hospitals: Though no significant difference in Governance, Monitoring and Supervision expenses were observed ( $p>0.05)$, there was an overall decrease from the provincial average in the Governance, Monitoring and Supervision.

Table 9:- Governance, monitoring \& supervision cost per annum (AFA)

\begin{tabular}{|c|c|c|c|c|c|c|c|c|c|c|c|c|}
\hline \multirow{2}{*}{$\begin{array}{l}\text { HFs by } \\
\text { geography }\end{array}$} & \multicolumn{2}{|c|}{ Yakawalang } & \multicolumn{2}{|l|}{ Waras } & \multicolumn{2}{|l|}{ Panjab } & \multicolumn{2}{|c|}{ Bamyan } & \multicolumn{2}{|c|}{ Kahmard } & \multicolumn{2}{|c|}{ Saighan } \\
\hline & AFA & USD & AFA & USD & AFA & USD & AFA & USD & AFA & USD & AFA & $\begin{array}{l}\text { US } \\
\text { D }\end{array}$ \\
\hline \multicolumn{13}{|l|}{ SHC } \\
\hline Rural & 91802 & 1836 & $\begin{array}{l}27343 \\
4\end{array}$ & 5469 & 0 & 0 & $\begin{array}{l}76641 \\
0\end{array}$ & $\begin{array}{l}1532 \\
8\end{array}$ & 0 & 0 & 0 & 0 \\
\hline $\begin{array}{l}\text { Isolated } \\
\text { Rural }\end{array}$ & 0 & 0 & $\begin{array}{l}15323 \\
6\end{array}$ & 3065 & 35271 & 705 & 0 & 0 & 0 & 0 & 0 & 0 \\
\hline $\begin{array}{l}\text { Deep } \\
\text { Rural }\end{array}$ & $\begin{array}{l}70291 \\
7 \\
\end{array}$ & $\begin{array}{l}1405 \\
8 \\
\end{array}$ & $\begin{array}{l}60009 \\
3 \\
\end{array}$ & $\begin{array}{l}1200 \\
2\end{array}$ & $\begin{array}{l}36628 \\
0 \\
\end{array}$ & 7326 & 0 & 0 & 0 & 0 & 0 & 0 \\
\hline & $\begin{array}{l}79471 \\
9 \\
\end{array}$ & $\begin{array}{l}1589 \\
4 \\
\end{array}$ & $\begin{array}{l}10267 \\
63 \\
\end{array}$ & $\begin{array}{l}2053 \\
5 \\
\end{array}$ & $\begin{array}{l}40155 \\
1 \\
\end{array}$ & 8031 & $\begin{array}{l}76641 \\
0 \\
\end{array}$ & $\begin{array}{l}1532 \\
8 \\
\end{array}$ & 0 & 0 & 0 & 0 \\
\hline \multicolumn{13}{|l|}{$\mathrm{BHC}$} \\
\hline Rural & $\begin{array}{l}54376 \\
4 \\
\end{array}$ & $\begin{array}{l}1087 \\
5\end{array}$ & $\begin{array}{l}10779 \\
86\end{array}$ & $\begin{array}{l}2156 \\
0 \\
\end{array}$ & $\begin{array}{l}82215 \\
8 \\
\end{array}$ & 16443 & $\begin{array}{l}36393 \\
1 \\
\end{array}$ & 7279 & $\begin{array}{l}4599 \\
68 \\
\end{array}$ & 9199 & $\begin{array}{l}2042 \\
85 \\
\end{array}$ & $\begin{array}{l}408 \\
6 \\
\end{array}$ \\
\hline $\begin{array}{l}\text { Deep } \\
\text { Rural }\end{array}$ & $\begin{array}{l}30850 \\
2\end{array}$ & 6170 & $\begin{array}{l}19648 \\
3\end{array}$ & 3930 & $\begin{array}{l}32897 \\
9\end{array}$ & 6580 & 0 & 0 & $\begin{array}{l}2623 \\
25\end{array}$ & 5247 & $\begin{array}{l}2287 \\
37\end{array}$ & $\begin{array}{l}457 \\
5\end{array}$ \\
\hline & $\begin{array}{l}85226 \\
6\end{array}$ & $\begin{array}{l}1704 \\
5 \\
\end{array}$ & $\begin{array}{l}12744 \\
69 \\
\end{array}$ & $\begin{array}{l}2548 \\
9 \\
\end{array}$ & $\begin{array}{l}11511 \\
37 \\
\end{array}$ & 23023 & $\begin{array}{l}36393 \\
1 \\
\end{array}$ & 7279 & $\begin{array}{l}7222 \\
93 \\
\end{array}$ & $\begin{array}{l}1444 \\
6 \\
\end{array}$ & $\begin{array}{l}4330 \\
22 \\
\end{array}$ & $\begin{array}{l}866 \\
0 \\
\end{array}$ \\
\hline \multicolumn{13}{|l|}{$\mathrm{CHC}$} \\
\hline Rural & $\begin{array}{l}17350 \\
75\end{array}$ & $\begin{array}{l}3470 \\
2 \\
\end{array}$ & $\begin{array}{l}44186 \\
8\end{array}$ & 8837 & 0 & 0 & $\begin{array}{l}19426 \\
37 \\
\end{array}$ & $\begin{array}{l}3885 \\
3 \\
\end{array}$ & $\begin{array}{l}5904 \\
92 \\
\end{array}$ & $\begin{array}{l}1181 \\
0\end{array}$ & $\begin{array}{l}4351 \\
10 \\
\end{array}$ & $\begin{array}{l}870 \\
2 \\
\end{array}$ \\
\hline Isolated & 0 & 0 & 0 & 0 & 0 & 0 & 0 & 0 & 0 & 0 & 0 & 0 \\
\hline
\end{tabular}




\begin{tabular}{|c|c|c|c|c|c|c|c|c|c|c|c|c|}
\hline \multicolumn{13}{|l|}{ Rural } \\
\hline $\begin{array}{l}\text { Deep } \\
\text { Rural }\end{array}$ & 0 & 0 & 0 & 0 & $\begin{array}{l}34925 \\
4\end{array}$ & 6985 & 0 & 0 & 0 & 0 & 0 & 0 \\
\hline & $\begin{array}{l}17350 \\
75\end{array}$ & $\begin{array}{l}3470 \\
2\end{array}$ & $\begin{array}{l}44186 \\
8\end{array}$ & 8837 & $\begin{array}{l}34925 \\
4\end{array}$ & 6985 & $\begin{array}{l}19426 \\
37\end{array}$ & $\begin{array}{l}3885 \\
3\end{array}$ & $\begin{array}{l}5904 \\
92\end{array}$ & $\begin{array}{l}1181 \\
0\end{array}$ & $\begin{array}{l}4351 \\
10\end{array}$ & $\begin{array}{l}870 \\
2\end{array}$ \\
\hline \multicolumn{13}{|l|}{ DH } \\
\hline $\begin{array}{l}\text { Deep } \\
\text { Rural }\end{array}$ & $\begin{array}{l}99500 \\
1\end{array}$ & $\begin{array}{l}1990 \\
0\end{array}$ & $\begin{array}{l}98824 \\
3\end{array}$ & $\begin{array}{l}1976 \\
5\end{array}$ & $\begin{array}{l}10717 \\
50\end{array}$ & $\begin{array}{l}21434.9 \\
98\end{array}$ & 0 & 0 & 0 & 0 & 0 & 0 \\
\hline
\end{tabular}

\section{Other Operational Expenses:-}

Other operational expenses include all other operations and maintenance costs for running health facilities. Correlation analyses indicated that the variation in salaries and wages and the particularities of the different health facilities may be able to statistically explain the differences in this cost item. This positive and moderate correlation was corroborated by the regression analyses . Forty-nine percent of the variation in the maintenance costs could be explained by the changes in salaries and wages across the different health facilities.

Health sub-centers: Spending on maintenance varied from a geographical cluster to another one $(\mathrm{p}<0.001)$. Waras district generated the highest average costs. Expenditures were at a basic level within the Bamyan District. Overall, costs were reduced when compared to the provincial average just in Waras it is increased.

Basic health centers: Variations in maintenance expenditures occurred across the geographical clusters $(\mathrm{p}<0.001)$. Waras and Panjbab displayed the highest average costs. Changes from the national average were predominant within the two distrcts (Waras and Panjab) districts.

Comprehensive health centers: There were significant differences between the geographical districts in the maintenance expenditures $(\mathrm{p}<0.01)$. The Waras, Panjab, Saighana and Kahmard districts were on average, the lowest costly districts but Bamyan and Yakawalang were on average, the most costly clusters. Overall, expenditures decreased compared to the provincial average. Largest variations from the national average were within the Yakawalang and Bamyan districts. The largest variations across the urban locations occurred within the Waras, Panjab, Saighan and Kahmard districts.

District hospitals: No changes in maintenance expenditures occurred across the geographical clusters, and overall expenditures remain the same compared to the provincial average.

Table 10:- Other Operational Expenses by Facility Across Geographic Districts and Rural/Urban Areas

\begin{tabular}{|c|c|c|c|c|c|c|c|c|c|c|c|c|}
\hline \multirow{2}{*}{$\begin{array}{ll}\text { HFs } & \text { by } \\
\text { Geography }\end{array}$} & \multicolumn{2}{|c|}{ Yakawalang } & \multicolumn{2}{|l|}{ Waras } & \multicolumn{2}{|c|}{ Panjab } & \multicolumn{2}{|c|}{ Bamyan } & \multicolumn{2}{|c|}{ Kahmard } & \multicolumn{2}{|c|}{ Saighan } \\
\hline & AFA & USD & AFA & USD & AFA & USD & AFA & USD & AFA & USD & AFA & USD \\
\hline \multicolumn{13}{|l|}{ SHC } \\
\hline Rural & 472 & 9 & 472 & 9 & 0 & 0 & 1417 & 28 & 0 & 0 & 0 & 0 \\
\hline Isolated Rural & 0 & 0 & 1889 & 38 & 472 & 9 & 0 & 0 & 0 & 0 & 0 & 0 \\
\hline \multirow[t]{2}{*}{ Deep Rural } & 1417 & 28 & 944 & 19 & 1417 & 28 & 0 & 0 & 0 & 0 & 0 & 0 \\
\hline & 1889 & 38 & 3305 & 66 & 1889 & 38 & 1417 & 28 & 0 & 0 & 0 & 0 \\
\hline \multicolumn{13}{|l|}{$\mathrm{BHC}$} \\
\hline Rural & 4433 & 89 & 8867 & 177 & 6650 & 133 & 2217 & 44 & 4433 & 89 & 2217 & 44 \\
\hline \multirow[t]{2}{*}{ Deep Rural } & 2217 & 44 & 2217 & 44 & 2217 & 44 & 0 & 0 & 2217 & 44 & 2217 & 44 \\
\hline & 6650 & 133 & 11084 & 222 & 8867 & 177 & 2217 & 44 & 6650 & 133 & 4434 & 89 \\
\hline \multicolumn{13}{|l|}{$\mathrm{CHC}$} \\
\hline Rural & 91215 & 1824 & 30405 & 608 & 0 & 0 & 91215 & 1824 & 30405 & 608 & 30405 & 608 \\
\hline Isolated Rural & 0 & 0 & 0 & 0 & 0 & 0 & 0 & 0 & 0 & 0 & 0 & 0 \\
\hline \multirow[t]{2}{*}{ Deep Rural } & 0 & 0 & 0 & 0 & 30405 & 608 & 0 & 0 & 0 & 0 & 0 & 0 \\
\hline & 91215 & 1824 & 30405 & 608 & 30405 & 608 & 91215 & 1824 & 30405 & 608 & 30405 & 608 \\
\hline \multicolumn{13}{|l|}{ DH } \\
\hline Deep Rural & 6933 & 139 & 6933 & 139 & 6933 & 138.7 & 0 & 0 & 0 & 0 & 0 & 0 \\
\hline
\end{tabular}




\section{Discussion and conclusion:- General observations:-}

The differences in costs regarding the health facilities may be explained by the nature of the health facilities. BHC facilities are facilities offering primary outpatient care. BHC facilities cover a population of about 15,000-30,000 and in circumstances where the population is isolated, the catchment population could be less than 10,000. Moreover, four to six health care workers constitute the minimal staffing requirements for a BHC. The HSC facilities, on the other hand, are intermediate health delivery facilities to bridge the services gap between Health posts and other BPHS levels of service provision. HSC facilities aim to increase access to health services for underserved populations living in remote areas. HSC facilities are, by definition have two technical staff. CHC and DH facilities are higher level of health care services providers. CHC facilities cover 30,000 to 60,000 people and offer a wider range of services than does the BHCs. Moreover, the size of the CHC staff is larger and includes doctors, nurses, midwives, laboratory and pharmacy technicians, etc. The DH facility serves patient with conditions that cannot be treated in other health care facilities in and offers comprehensive outpatient and inpatient care. The estimated population covered is about 100,000-300,000 and DH facilities are staffed by many doctors and specialists. Hence, given the patient volume levels and perhaps economies of scale which can play a factor it may not be surprising to observe lower per capita costs at the DH level than in other levels. With all this in mind statistically it is not possible to observe any overlap in the spending patterns of the selected health facilities either. The spending pattern further shows that there are specificities and overlap in the resources utilization across the locations of the health facilities' target areas. The costs associated with health services provision in the rural/urban locations are largely related to the salary payment and their related hardship allowance. The extension of the list of drugs and the additional resource costs associated with, for example, the equipment requirements specific to each health facility (e.g. provision of ECG at DH and CHC, privacy Partitions for Delivery Rooms in BHC, CHC and DH facilities, etc.) may further explains this findings.

Based on the distribution alongside with the districts, the Yakawalang and Waras districts consistently displayed the highest average staff costs and Saighan and Kahmard districts the lowest ones in all the health facilities. With drugs and disposables expenditures, while the Waras and Panjab appeared to be the most costly districts in all health facilities, the Saighan and Kahmard districts displayed basic spending. With the expenditures on maintenance, equipment and other operational expenses, the Saighan and Kahmarad districts had the lowest costs in all health facilities. The Yakawalang and Bamyan districts were the one with the highest average costs in the SHC, BHC, $\mathrm{CHC}$ and DH facilities.

These differences cannot be easily explained and may result from geographical, ethnic and cultural factors and security issues. These factors raise the question of the accessibility of the population to health care services and the number of people covered. Because population figures in the selected province is difficult to come by, it is not always possible to obtain a per capita estimate. In addition, as I am unable to determine care consumption differences between locations, cost variations cannot be directly linked to any specific care needs of a given population.

\section{Study Limitations:-}

Finding a proxy to estimate caseloads poses challenges in Afghanistan. The costs of drugs and disposables cannot be used as the proxy for health facility caseloads as the supplies facilities receive are a fixed pre-determined amount independent of actual consumption. Therefore, I have accounted for these expenses in real numbers in lieu of adjusting for caseload.

In the absence of data on the adherence to established clinical case management protocols specific to packages of care, this study has been unable to define the cost of managing illness.

\section{Annex. Data collection tool:-}

The following is selection of some of the information collected to obtain costs

Facility Profile Province District Head of Facility

Area in Sq. meter

Number of consultation rooms

Number of treatment rooms

Number of inpatient beds

Distance from the nearest urban location 
Years of operation

Capital Assets

List of assets with detail including quantity, make/model, year of purchase, cost during year of purchase

Human Resources

Medical personnel by type, number of hired personnel, number of active personnel, salaries of personnel

Drugs and Disposables (per quarter over 12 months) Drug type, strength of dose, quantity received and consumed

Workload by Intervention (per month over 12 months) Post-partum Care

Antenatal Care

Vitamin A supplementation (mother)

Diagnosis of pregnancy

Treatment of anaemia

Antenatal visits

Tetanus toxoid administration

Treatment of puerperal infection

Iron \& folic acid supplementation

Multi-micronutrient supplementation

Diagnosis of anaemia

Treatment of malaria

Treatment of asymptomatic urinary tract infection

Antibiotics

Breast examination

Counselling on birth spacing and exclusive breast feeding

Provide birth spacing methods

Condoms

Treatment of symptomatic urinary tract infection

Oral contraceptive pills

Treatment of anaemia

Screening and management of sexually transmitted

Injectable progesterone

diseases

Diagnosis of HT in pregnancy

Diagnosis of pre-eclampsia/eclampsia

Treatment of incomplete miscarriage/abortion

Diagnosis of ectopic pregnancy

\section{Recommendation and policy implication:-}

Findings from this study reveal several interesting trends across districts, rural and urban locations, and BPHS facilities. First of all, it appears that the revision of the National Salary Policy and its translation into salary supplements to reduce the differences among workers had an impact on the health expenditures. Maintaining a regular supply of essential drugs, one of the key element of the BPHS, also generated costs that had non-negligible economic repercussions. Finally, costs related to the procurement and management of supplies, activities and transport and maintenance services were also major components of the BPHS expenditures. These costs drivers mainly explain the differences in BPHS costs among the selected province and the implemented health facilities.

Designing a central process to evaluate and monitor care consumption would also be very useful. This can help both the MoPH and NGO's providing care to better plan, prepare for different population needs, and aid authorities in prioritizing services which are high in demand but short in supply.

\section{Reference:-}

1. ANDS. (2007). Draft Health and Nutrition Strategy 2008-2013. Afghanistan National Development Strategy Islamic Republic of Afghanistan ANDS

2. Bartlett, L \& Crouse C, Bowens, S. et al. (2002). Maternal Mortality in Afghanistan: magnitude, causes, risk factors and preventability, summary finding. UNICEF/CDC/MOH

3. JHU/IIHMR. (2007) Afghanistan Health Sector Balanced Scorecard National and Provincial Results. Round 3 2006. Johns Hopkins University and Indian Institute of Health Management Research

4. JHU/IIHMR. (2006). Executive Summary, Afghanistan Household Survey 2006. Johns Hopkins University and Indian Institute of Health Management Research.

5. Ministry of Public Health (2010). A Basic Package of Health Services for Afghanistan Islamic Republic of Afghanistan. Ministry of Public Health of Afghanistan.

6. Thoebald, S. (Nov, 2007). Qualitative Research Methods: planning and designing a qualitative study. A power point presentation. Liverpool School of Tropical Medicine.

7. UNAMA/ Solidarities survey of 2003. 